\title{
RESILIENSI KELUARGA PASIEN PASCA RAWATAN DI RUMAH SAKIT JIWA PROVINSI JAWA BARAT
}

\author{
Devina Nelviana Pentariputri \\ Politeknik Kesejahteraan Sosial, devinanelvianap@gmail.com \\ Pribowo \\ Politeknik Kesejahteraan Sosial, pribowostks@gmail.com \\ Aam Muharam \\ Politeknik Kesejahteraan Sosial, kang_a2m@yahoo.co.id
}

\begin{abstract}
Familiy resilience comprises three key processes that help the ability of a family development to face difficult situations. Thus, a family can overcome the difficulties and develop from the difficulties. The aim of this research attempts to assess 1) description of the informant's identitiy; 2) family's belief system in viewing a problem; 3) organization's pattern or relationship runned by the family; 4) communication process in the family; and 5) family's expectations towards their conditions. The method used to assess this research is descriptive qualitative method and the data sources used are primary and secondary data sources. To determine the data sources, this research uses a purposive technique. The data collection techniques used to assess in this research are 1) in-depth interview; 2) observation; and 3) study documentation. The data validation techniques used in this research are the extension of observation, the consistency of observation, and the triangulation technique. The result of this research shows all families of schizophrenic patients have a different resilience condition.
\end{abstract}

Keywords:

Familiy resilience, Schizophrenia Patients, Psychiatric Hospital in West Java

\begin{abstract}
Abstrak
Resiliensi keluarga meliputi tiga proses kunci yang membantu perkembangan kemampuan keluarga untuk menghadapi situasi sulit yang dihadapi oleh keluarga sehingga keluarga dapat mengatasi kesulitan dan berkembang dari kesulitan tersebut. Penelitian ini bertujuan untuk mengkaji tentang 1) gambaran identitas informan 2) sistem keyakinan yang dimiliki keluarga pasien dalam memandang suatu masalah 3) pola organisasi atau hubungan yang dimiliki oleh keluarga pasien 4) proses komunikasi yang terjadi didalam keluarga pasien 5) Harapan keluarga mengenai kondisi keluarganya. Metode yang digunakan dalam penelitian ini adalah metode kualitatif deskriptif. Sumber data yang digunakan adalah sumber data primer dan sumber data sekunder. Penentuan sumber data dalam penelitian ini menggunakan teknik purposive. Teknik pengumpulan data yang digunakan dalam penelitian ini adalah 1) wawancara
\end{abstract}


mendalam, 2) observasi, dan 3) studi dokumentasi. Teknik pemeriksaan keabsahan data dalam penelitian ini menggunakan perpanjangan pengamatan, keajegan pengamatan dan triangulasi teknik. Hasil penelitian menunjukan kondisi resiliensi yang dimiliki keluarga pasien yang mengalami skizofrenia kondisi keluarga memiliki kondisi resiliensi keluarga yang berbeda.

\section{Kata Kunci:}

Resiliensi Keluarga, Pasien Skizofrenia, Rumah Sakit Jiwa Provinsi Jawa Barat. 


\section{PENDAHULUAN}

Keluarga merupakan sebuah institusi terkecil dalam masyarakat. Dari keluargalah awal sebuah generasi terbentuk. Itulah sebabnya, bangunan sebuah keluarga haruslah kuat agar mampu menghasilkan generasi tangguh. Ketangguhan keluarga ditentukan oleh landasan pembangun keluarga. Resiliensi sering diartikan sebagai sebuah ketahanan, Ketahanan secara umum didefinisikan sebagai kemampuan untuk mengatasi kesulitan, atau untuk berkembang meskipun menghadapi tantangan dan kesulitan dalam hidup. Konsep ketahanan menjadi semakin populer dalam penelitian mengenai cara-cara individu, keluarga dan komunitas pulih dari trauma, seperti trauma akibat bencana, perang, atau kehilangan anggota keluarga. Telaah mengenai ketahanan keluarga menjadi penting karena keluarga adalah tempat individu tumbuh dan berkembang. Selain itu, keluarga merupakan tempat berlangsungnya aktivitas utama individu sehingga keluarga menjadi penentu kualitas seseorang menghadapi masa depan. Untuk memahami proses resiliensi keluarga maka tinjauan multisistem diperlukan dalam melihat kondisi keluarga. Keluarga memegang peran penting dalam upaya proses penyembuhan orang dengan gangguan jiwa dirumah maupun di Rumah Sakit.

Pekerja sosial di Rumah Sakit Jiwa Provinsi Jawa Barat menjelaskan bahwa pasien skizofrenia yang menjalani rawat inap dan yang sudah merasakan dipasung oleh keluarga pasien pada tahun 2019 berjumlah 76 kasus yang berasal dari wilayah kabupaten atau kota di Provinsi Jawa Barat, Pekerja Sosial di Rumah Sakit Jiwa Provinsi Jawa Barat menjelaskan tidak jarang pekerja sosial kesulitan menghubungi keluarga pasien skizofrenia yang menjalani rawat inap terhitung pada tahun 2019 jumlah pasien yang sudah dihubungi oleh pekerja sosial berjumlah 2.559 keluarga, penjemputan pasien oleh keluarga bukanlah hal mudah bagi pihak keluarga banyak keluarga yang belum siap dengan kepulangan pasien, ketidaksiapan keluarga inilah yang menujukan resiliensi keluarga terhadap kepulangan pasien pasca di rawat kesiapan yang harus disiapkan oleh keluarga terhadap kesulitan atau hambatan apa saja yang akan terjadi didalam maupun yang berasal dari luar lingkungan keluarga.

Perawat salah satu ruangan rawat inap menjelaskan setiap bulan dari 50 orang pasien kurang lebih hanya 20-30 keluarga yang membesuk pasien yang ada. Kebanyakan alasan keluarga tidak menjenguk adalah jarak antara rumah sakit dan rumah terlampau jauh, kesulitan transportasi untuk keluarga bisa menjenguk pasien, ada juga keluarga yang sibuk dengan pekerjaan sehingga tidak bisa menjenguk pasien di Rumah Sakit, Pada Kondisi seperti ini menjadi suatu penilaian resiliensi suatu keluaga pasien yang sering dibesuk oleh keluarga merupakan hal yang sangat penting karena salah satu bentuk rasa kepedulian dan kasih sayang keluarga kepada pasien sehingga terbentuklah suatu keluarga yang resilien. Akan tetapi banyak pasien yang jarang dan hampir tidak pernah dibesuk oleh keluarga nya sampai kepulangan pasien tersebut.

Tenaga medis seperti Dokter dan Perawat serta Pekerja Sosial menjelaskan penolakan atau kurangnya penerimaan keluarga terhadap pasien skizofrenia yang menjalani rawat inap baik di Rumah Sakit Umum maupun Rumah Sakit Jiwa masih menjadi salah satu permasalahan yang terdapat dalam penanganan pasien, selain permasalahan yang umum dialami oleh 
keluarga pasien skizofrenia seperti keterbatasan fasilitas dan layanan kesehatan, kendala biaya, akses informasi yang terbatas dan lain sebagainya.

Penerimaan keluarga merupakan suatu efek psikologis dan perilaku dari keluarga pada pasien skizofrenia yang bisa ditunjukkan melalui kepedulian, kelekatan, dukungan dan pengasuhan dimana keluarga dapat memberikan perawatan yang dibutuhkan oleh anggota keluarganya yang mengalami skizofrenia sebagai wujud dari rasa kekeluargaan, dan salah satu wujud ekspresi penerimaan keluarga atas keberadaan pasien skizofrenia di dalam keluarga (Elizabeth B.Hurlock, 2001). Kenyataannya pilihan keluarga untuk merawat dan tinggal bersama pasien skizofrenia akan menimbulkan permasalahan yang akan dialami oleh seluruh anggota keluarga. Perubahan yang dapat memicu munculnya stress pada keluarga antara lain gejala skizofrenia yang mengganggu, perubahan rutinitas dan aktivitas seluruh anggota keluarga sehari-hari, ketegangan hubungan keluarga dengan lingkungan sosial, kehilangan dukungan sosial, berkurangnya waktu luang dan kondisi keuangan yang memburuk (Stengard, 2003).

Keluarga di harapkan dapat menangani stress akibat perubahan perilaku yang dialami oleh anggota keluarga yang mengalami skizofrenia berdasarkan hasil wawancara dengan salah satu pasien menjelaskan tidak jarang keluarga mengalami ketakutan. Ketakutan tersebut berupa stigma masyarakat terhadap keluarganya, penilaian terhadap individu yang mengalami skizofrenia beserta keluarganya yang dapat mempengaruhi hubungan dengan tetangga dan teman-teman. Ketakutan terhadap Stigma sosial dapat membuat anggota keluarga menjauhkan diri dari penderita skizofrenia. Walaupun dengan tindakan tersebut keluarga merasa tidak nyaman dan bahkan muncul rasa bersalah, lefley (Dalam Koolaee et al, 2009). Dengan demikian Skizofrenia tidak hanya menimbulkan penderitaan bagi individu penderitanya, tetapi juga bagi orang-orang yang berada disekitar penderita skizofrenia. Dalam hal ini keluargalah yang paling merasakan dampak dari hadirnya skizofrenia ditengah-tengah keluarga mereka.

Keluarga yang merawat penderita gangguan psikotik 50\%-80\% menunjukan tingginya beban merawat anggota keluarganya. Meningkatnya beban akan mempengaruhi angka kejadian relaps dan beratnya gejala yang timbul pada penderita (Nasr \& Kausar, 2009) Hal ini dibuktikan pada penelitian terdahulu yang dilakukan oleh Yunika Nur Mastiyas bahwa semakin tinggi tingkat resiliensi keluarga, maka semakin jarang frekuensi kekambuhan, berlaku pula sebaliknya yaitu semakin rendah tingkat resiliensi keluarga maka sering frekuensi kekambuhan pasien tersebut. Keluarga membutuhkan dukungan untuk membantu mengatasi beban tersebut. Salah satu pendekatannya adalah dengan mengeksplorasi resiliensi keluarga untuk memperbaiki kehidupan keluarga dan penderita skizofrenia. Resiliensi keluarga mencangkup kemampuan untuk mengembangkan kemampuan interpersonal yang adaptif dan kualitas keluarga yang positif (Heru \& Drury, 2011), keluarga memiliki peranan yang penting dalam kehidupan pasien skizofrenia, Keluarga merupakan bagian terpenting untuk membentuk kebudayaan yang sehat didalam keluarga itu sendiri. Keluarga dijadikan unit pelayanan karena masalah kesehatan keluarga saling berkaitan satu sama lain mempengaruhi 
antara sesama anggota keluarga dan juga akan mempengaruhi keluarga yang ada disekitarnya. Akan tetapi membangun ketahanan atau resiliensi keluarga memiliki cara yang berbeda-beda tergantung faktorfaktor dan kondisi keluarga yang berdampak kepada pasien skizofrenia itu sendiri. Dengan demikian resiliensi keluarga merupakan hal yang sangat penting bagi pemulihan pasien skizofrenia pasca rawat demi pemulihan kondisi biologis, psikologis dan sosial pasien tersebut sehingga bisa menimalisir kekambuhan dari pasien tersebut.

\section{METODE}

Desain penelitian yang akan di lakukan pada penelitian ini adalah penelitian deskriptif kualitatif. Metode penelitian kualitatif yang digunakan untuk mendapatkan data yang mendalam,data tersebut yaitu data yang mengandung makna atau data yang sebenarnya sumber data dibagi menjadi dua yaitu sumber data primer yaitu ayah,ibu,kakak atau adik sumber data sekunder yaitu berasal dari data tertulis studi dokumentasi, kegiatan, foto-foto kegiatan, laporan dan lain-lain.

Cara menemukan informan yang peneliti lakukan adalah dengan teknik purposive yaitu orang yang di jadikan sample bedasarkan pertimbangan yang sesuai dengan tujuan penelitian. Bedasarkan teknik tersebut, maka informan dalam penelitian ini adalah satu orang yang menjadi significant other yang secara langsung merawat dan mengetahui kondisi perkembangan anggota keluarganya yang mengalami gangguan jiwa yang sudah mendapatkan pelayanan dari Rumah Sakit Jiwa Provinsi Jawa Barat yang berdomisili di area kota atau kabupaten Bandung dan Bandung Barat akan tetapi dalam proses pengumpulan data informan pendukung yaitu anggota keluarga lain yang tinggal bersama pasien.

Pengumpulan data tidak di pandu oleh teori, tetapi di pandu oleh fakta-fakta yang di temukan pada saat penelitian di lapangan. Setelah pengumpulan data penelitian ini mengunakan triangulasi teknik dengan Membandingkan data hasil observasi/pengamatan dengan hasil indepth interview yang sudah dilakukan kepada salah satu anggota keluarga pasien. Membandingkan apa yang disampaikan informan di depan umum, dengan apa yang disampaikan secara pribadi pada waktu wawancara. Membandingkan hasil indepth interview dengan data sekunder yang bisa digunakan.

\section{HASIL PENELITIAN}

Significant others yang menjadi informan dalam penelitian ini yaitu anggota keluarga pasien yang mengalami gangguan jiwa yang sudah mendapatkan pelayanan dari Rumah Sakit Jiwa Provinsi Jawa Barat berjumlah dua orang, 1 (satu) subjek adalah ibu dari pasien AF dan 1 (satu) subjek adalah ibu dari pasien PP. Kedua subjek tersebut bernisial R dan A . berdomisili di Kota dan Kabupaten Bandung Barat.

Subjek $\mathrm{R}$ adalah seorang perempuan berusia 46 tahun merupakan ibu kandung dari pasien AF yang berusia 24 tahun yang sudah mendapatkan pelayanan dari Rumah Sakit Jiwa Provinsi Jawa Barat karena mengidap Skizofrenia Katatonik akibat penyalahgunaan zat. $\mathrm{R}$ merupakan anggota keluarga $\mathrm{R}$ yang merawat dan mengetahui kondisi AF dari awal pertama AF memunculkan beberapa gejala gangguan jiwa dan akhirnya keluarga memutuskan untuk membawa AF untuk di rawat di Rumah Sakit Jiwa sejumlah tiga kali. 
Karena $\mathrm{R}$ tinggal bersama suami nya di Bandung membuat $\mathrm{R}$ jarang berkomunikasi dan memantau AF semenjak AF memunculkan gejala gangguan jiwa $R$ seringkali menghabiskan waktu untuk merawat dan memantau perkembangan AF karena saat ini AF tinggal bersama nenek nya.

Subjek A merupakan ibu dari kandung berusia 49 tahun dari pasien PP yang berusia 27 tahun yang sudah mendapatkan pelayanan dari Rumah Sakit Jiwa Provinsi Jawa Barat karena mengidap skizofrenia afektif karena masalah keluarga . PP baru satu kali mendapatkan pelayanan dari Rumah Sakit Jiwa pertama pada tahun 2019. PP sempat mendapatkan pelayanan rawat jalan akan tetapi tidak ada pengaruh dan dampak perkembangan yang positif dari PP akhirnya di rujuk ke Rumah Sakit Jiwa Provinsi Jawa Barat untuk mendapatkan pelayanan perawatan. A merawat dan mencoba menghadapi kondisi PP yang seperti itu sampai akhirnya harus dirawat di Rumah Sakit Jiwa Provinsi Jawa Barat setelah selesai menjalani perawatan $\mathrm{R}$ pulang ke kontrakan sampai akhirnya dikontrakan yang barunya PP kambuh kembali karena jarang meminum obat sampai akhirnya diusir lagi oleh tetangga nya PP dan ibu nya berpindah kontrakan sebanyak 4 kali karena tidak diterima oleh lingkungan sekitar. PP sangat mengetahui perkembangan yang di alami oleh PP semenjak gejala awal yang Nampak ampai selesai menjalani perawatan dari Rumah Sakit Jiwa akan tetapi ada saja hambatan dan kesulitan yang dirasakan ketika A harus terus merawat PP di rumah.

Hasil wawancara kedua subjek penelitian yaitu kedua subjek merupakan ibu kandung pasien yang merawat dan mengetahui kondisi pasien yang memiliki usia yang tidak jauh berbeda yaitu ibu $\mathrm{R}$ berusia 46 tahun dan ibu A berusia 49 tahun. Penyakit gangguan jiwa yang dialami anak dari ibu $\mathrm{R}$ yaitu skizofrenia katatonik sementara anak dari ibu A mengalami gangguan jiwa skizofrenia afektif dari kedua jenis gangguan jiwa skizofrenia tersebut memiliki gejala yang berbeda sehingga respon, hambatan dan kesulitan yang dialami yang secara langsung merawat pasien pun berbeda. Kedua subjek penelitian ini memiliki anggota keluarga yang sudah mendapatkan pelayanan dan perawatan dari Rumah Sakit Jiwa sehingga saat ini anggota keluarga yang memiliki gangguan jiwa tersebut sedang berada dirumah dan membutuhkan dukungan dan perawatan dari keluarga demi mendukung anggota keluarga tersebut untuk pulih dan tetap mendapatkan pelayanan pengobatan dengan rawat jalan yang harus didukung dan didampingi oleh keluarga.

\section{Aspek-aspek Resiliensi Keluarga Keluarga Pasien Pasca Rawatan.}

Walsh (2006) menyebutkan kerangka family resilience dibangun melalui tiga komponen yang menjadi proses kunci family resilience. Ketiga proses kunci tersebut adalah sistem keyakinan, pola organisasi, dan proses komunikasi sebagai berikut :

\subsection{Sistem Keyakinan Yang Dimiliki dan Diyakini Keluarga Pasien Skizofrenia}

\section{Memberi Makna Pada Kesulitan}

Penjelasan kedua subjek mengenai memberi makna pada kesulitan yang berkaitan dengan peristiwa-peristiwa yang terjadi didalam keluarga memiliki pendapat yang berbeda sesuai dengan kondisi yang terjadi didalam keluarga. Dari kedua subjek yang diteliti kesulitan yang terjadi merupakan 
dampak dari peristiwa masa lalu yang sangat berpengaruh kepada kondisi kesehatan jiwa seperti perceraian dan peristiwa pelecehan sexual, Sehingga dari kedua subjek tersebut memiliki pendapat yang berbeda. Subjek pertama makna hambatan dan kesulitan dalam merawat anaknya yang saat ini mengalami gangguan jiwa merupakan hal yang merepotkan dan menganggu pekerjaan nya. Sementara subjek kedua menjelaskan mencoba untuk menerima segala bentuk hambatan dan kesulitan yang dirasakan selama merawat PP karena A merasa semua yang terjadi PP juga merupakan kesalahan nya juga.

\section{Pandangan Positif}

Pandangan positif terlihat pada inisiatif dan usaha yang gigih dari anggota keluarga dalam menghadapi kesulitan, serta menguasai situasi yang dapat dikendalikan dan menerima situasi yang tidak dapat dikendalikan, kesulitan yang didapatkan yaitu tanggapantanggapan yang berasal dari dalam dan luar keluarga yang tidak jarang berupa tanggapan buruk mengenai anggota keluarganya.

Subjek pertama berpendapat bahwa tanggapan buruk yang diberikan lingkungan sekitar merupakan hal yang tidak selalu harus ditanggapi dan seharusnya yang dilakukan adalah tetap berfikiran postif meskipun terdapat stigma dan labeling dari orang-orang di lingkungan sekitar meskipun rasa takut dan khawatir yang dirasakan subjek kedua karena seringkali mendapatkan pengusiran dari lingkungan sekitar. Dari pernyataan yang diberikan oleh subjek kedua memperlihatkan kurang mampu untuk memandang suatu masalah dengan optimis dan percaya diri dalam menghadapi tanggapan buruk yang diterima kepada anaknya.

\section{Transenden Dan Spritualitas}

Transenden dan spiritualitas berkaitan dengan kepercayaan dan keyakinan keluarga dalam memandang peristiwa yang terjadi, Dari kedua subjek tersebut menunjukan adanya perbedaan dalam memandang anggota keluarganya yang mengalami gangguan jiwa yang berkaitan dengan nilai-nilai dan kepercayaan tertentu dari subjek pertama sangat mempercayai kondisi gangguan jiwa yang dialami oleh anak berkaitan dengan halhal mistis atau ghaib karena didaerah tempat tinggalnya masih kental dengan hal-hal seperti itu. Akan tetapi berbeda dengan subjek kedua yang tidak sama sekali mempercayai kondisi anaknya berkaitan dengan hal-hal mistis atau ghaib, memandang kondisi yang dialami oleh anaknya merupakan kesalahan nya. Akan tetapi dari kedua aspek tersebut memandang memiliki anggota keluarga yang mengalami gangguan jiwa adalah sebuah bentuk cobaan atau ujian untuk nya yang harus dihadapi.

\subsection{Pola organisasi atau hubungan keluarga}

\section{Fleksibilitas dan kemampuan beradaptasi}

Fleksibilitas dapat terwujud dengan tetap dilaksanakannya kegiatan dan kebiasaan yang rutin dilakukan keluarga sehingga dapat menjaga kontinuitas dan mengembalikan stabilitas keluarga yang dapat mendorong resiliensi seperti rekreasi dan tamasya keluarga serta kemampuan keluarga dalam beradaptasi.

Dari kedua subjek yang diteliti menunjukan adanya perbedaan dalam fleksibilitas dan kemampuan beradaptasi ditandai dengan subjek pertama yang memiliki lingkungan rumah yang didominasi oleh hubungan keluarga sehingga respon yang diberikan juga baik dan seringkali melakukan rekreasi 
dengan keluarganya berbeda hal nya dengan keluarga dari subjek kedua yang tidak pernah melakukan rekreasi sekalipun bersama keluarga apalagi tetangga nya karena seringkali berpindah-pindah tempat tinggal karena diusir oleh tetangga dilingkungannya. Sebelum pindah ke lokasi kontrakan saat ini lingkungan kontrakan atau tempat tinggalnya sebelumnya seringkali memberikan respon tidak baik kepada keluarga.

\section{Keterhubungan}

Keterhubungan bisa ditandai dengan pola komunikasi yang terjadi antara antar keluarga maupun dengan tetangga sekitar, anggota keluarga lain dengan anggota keluarga yang mengalami gangguan jiwa, tetangga lingkunga dengan anggota keluarga yang mengalami gangguan jiwa dan pihak rumah sakit yang sering dihubungi .

Dari kedua subjek yang diteliti menunjukan adanya perbedaan dalam aspek keterhubungan dimana subjek pertama memiliki hubungan yang baik dengan anggota keluarga lain, sementara subjek kedua kurang karena jarak. Keterhubungan yang dimiliki oleh setiap keluarga tentu berbeda sesuai dengan kondisi dari komponen keluarga itu sendiri, keluarga seharusnya menjaga pola komunikasi yang terjadi didalam keluarga , maupun keluarga itu sendiri dengan lingkungan sekitar. Seperti pada kondisi yang dialami oleh subjek kedua yang menutup diri dengan lingkungan sekitar agar tetangga di daerah tempat tinggal nya saat ini tidak mengetahui keadaan anaknya yang sebenarnya karena takut di usir lagi.

\section{Sumber daya sosial dan ekonomi atau pemenuhan sosial}

Pendapat kedua subjek mengenai sumber daya sosial dan ekonomi atau pemenuhan sosial didalam keluarga memiliki kesamaan yaitu hanya memiliki jaminan layanan kesehatan yang hanya dimiliki oleh anggota keluarga nya yang mengalami gangguan jiwa untuk mendapatkan perawatan dari rumah sakit jiwa sementara untuk anggota keluarga lain tidak memiliki jaminan kesehatan lainnya ataupun program bantuan dari pemerintah. Kondisi keluarga dari kedua subjek ini yang menjadi tulang punggung keluarganya adalah anak pertama dari keluarga tersebut yang banyak menanggung biaya perekenomian keluarga ataupun biaya berobat dari anggota keluarganya yang mengalami gangguan jiwa untuk melakukan rawat jalan di rumah sakit.

\subsection{Proses komunikasi antar keluarga yang terjalin dalam menangani dan merawat anggota keluarga yang memiliki gangguan jiwa skizofrenia}

\section{Kejelasan}

Kejelasan merupakan kemampuan keluarga menceritakan mengenai hambatan secara langsung dan jujur dalam merawat anggota keluarga yang mengalami gangguan jiwa kepada anggota keluarga lain. Dari kedua subjek membuktikan bahwa hanya kepada orang-orang yang dianggap nyaman, dan dipercayai nya subjek tersebut bisa menceritakan semua hambatan secara jujur dan terbuka mengenai hambatan dalam merawat anggota keluarganya yang mengalami gangguan jiwa. Karena menganggap orang lain selain orang tersebut tidak akan memahami dan memberikan jalan keluar ketika terdapat hambatan dan kesulitan selain itu yang dikhawatirkan adalah ketika kedua subjek tersebut mendapatkan respon yang tidak baik. 


\section{Ungkapan emosi}

Keluarga yang berfungsi dengan baik dapat mengungkapkan emosi yang dirasakannya dengan nyaman baik emosi positif seperti bahagia, berterima kasih, cinta, dan harapan maupun emosi negative seperti sedih, takut, marah, dan kecewa kepada anggota keluarga yang dianggap tempat yang pas untuk menceritakan semua perasaan nya. Cara dari setiap subjek dalam mengungkap emosi ataupun perasaan nya tentunya berbedabeda. Kedua aspek membuktikan pengungkapan emosi dan perasaan yang dirasakan masing-masing kedua subjek itu dapat dilakukan ketika ada orang yang menurut subjek memahami perasaan nya sehingga segala perasaan yang dirasakan khususnya dalam merawat anggota keluarganya yang mengalami gangguan jiwa dapat diungkapkan dengan lega.

\section{Pemecahan \\ Masalah \\ Kolaboratif}

Proses pemecahan masalah yang efektif didalam keluaraga meliputi identifikasi masalah dan penyebab terkait, brainstroming mengenai kemungkinan pemecahan masalah, saling berbagi dalam mengambil keputusan,berfokus pada tujuan dengan mencoba mengambil langkah-langkah konkret, dan belajar dari kesalahan yang dilakukan didalam keluarga tersebut.

Dari kedua subjek memiliki pola yang berbeda dalam usaha pemecahan masalah subjek pertama lebih memilih untuk mendiskusikan bersama suaminya bagaimana upaya penanganan anaknya yang pada saat itu menujukan gejala yang sudah tidak bisa dikendalikan oleh keluarga dan terdapat suatu kesepakatan bersama, akan tetapi subjek kedua lebih memilih untuk mengikuti pola rujukan yang diberikan oleh rumah sakit sebelumnya dan tidak mendiskusikan hal tersebut dengan anggota keluarga lain selain anak terakhirnya.

Dari kedua subjek tersebut membuktikan bahwa terdapat keluarga yang melakukan diskusi terlebih dahulu dan ada juga yang mengkuti arahan dari luar dalam pemecahan permasahalan yang dialami oleh keluarga tersebut khususnya dalam merawat anggota keluarga yang mengalami gangguan jiwa. Diskusi yang dilakukan oleh setiap keluarga mempengaruhi kondisi kelekatan dari setiap anggota keluarga tersebut semakin sering setiap anggota keluarga mencoba merumuskan upaya pemecahan masalah semakin dekat juga hubungan emosional yang terjadi

\section{PEMBAHASAN}

Resiliensi keluarga pasien skizofrenia merupakan bentuk kelenturan keluarga dalam menghadapi masalah atau peristiwa -peristiwa yang terjadi terhadap pasien skizofrenia ketika dirawat dirumah. Peristiwa yang terjadi didalam keluarga memiliki keterkaitan dengan terjadinya gangguan jiwa yang dialami oleh anggota keluarga tersebut pada subjek pertama tidak hanya peristiwa didalam keluarga akan tetapi dari keyakinana yang diyakini oleh keluarga tersebut. Gejala-gejala yang terjadi pada anggota keluarga yang mengalami gangguan jiwa berbeda-beda sesuai dengan jenis gangguan jiwa yang dialami oleh anggota keluarga tersebut. gejala-gejala tersebut membuat keanehan dan tanggapan yang berbeda setiap orang khususnya tetangga dan lingkungan sekitar. Bagi orang yang tidak memahami betul gejala tersebut akan memberikan stigma atau label kepada orang tersebut dengan istilah "orang gila" karena melakukan kegiatan diluar batas kewajaran.

Tanggapan buruk yang diterima berimbas pada keluarga yang mendengar hal 
tersebut menimbulkan perasaan sakit hati khususnya kepada orang yang selama ini merawat orang yang mengalami gangguan jiwa tersebut. Pada subjek kedua tanggapan buruk tersebut tidak hanya pada verbal akan tetapi sampai bentuk pengusiran terhadap keluarga . rasa kejenuhan dalam menanggapi tanggapan buruk tersebut mengalami perbedaan dalam memaknainya dengan hal yang tidak perlu untuk ditanggapi dan dibiarkan saja orang sekitar mengetahui keadaan anaknya dan berpendapat apa saja kepada anaknya dan malah merasa takut apabila tanggapan buruk itu ada kembali dan membuatnya terusir lagi dan saat ini memilih untuk menyembunyikan kondisi anak nya yang pernah di rawat di rumah sakit jiwa.

Sistem keyakinan keluarga pun dipengaruhi oleh transenden dan spiritualitas keluarga itu sendiri hasil wawancara peneliti faktor penyebab keluarga adapun faktor lain seperti hal-hal mistis atau ghaib sehingga menimbulkan gejala aneh seperti halusinasi dan delusi yang dipercaya oleh keluarga.

Sistem keyakinan keluarga yang berkenaan denhan hal-hal mistis atau ghaib pun bisa tidak berpengaruh yaitu keluarga mempercayai kondisi gangguan jiwa yang dialami oleh anaknya merupakan dampak peristiwa dulu.

Resiliensi keluarga juga dipengaruhi oleh pola organisasi dan hubungan keluarga yang mencangkup fleksibilitas, keterhubungan, dan sumber daya sosial dan ekonomi adapaun fleksibilitas dan kemampuan beradaptasi keluarga seperti waktu keluarga dalam melaksanakan rekreasi bersama-sama ataupun tamasya keluarga didalam keluarga subjek pertama menjelaskan pernah melakukan rekreasi bersama anaknya yang mengalami gangguan jiwa dan anggota keluarga nya yang lain sebagai bentuk agar anaknya tidak merasa jenuh dan tidak bosan terus berdiam dirumah manfaat dalam rekreasi tersebut adalah mengurangi ketegangan yang terdapat didalam keluarganya.berbeda dengan kondisi keluarga ada juga keluarga yang tidak pernah melakukan rekreasi keluarga, sehingga didalam hubungan keluarga tersebut terdapat ketegangan antara anaknya yang mengalami gangguan jiwa maupun dengan anggota keluarga nya yang lain.

Bentuk fleksibilitas yang dilakukan oleh keluarga fleksibilitas dapat dilihat dari keterlibatan keluarga tersebut dengan kegiatan masyarakat sekitar subjek pertama menjelaskan anaknya ketika selesai mejalani perawatan dari rumah sakit ikut serta dalam kegiatan ronda malam bersama teman-teman dan tetangganya tanpa melihat bahwa anaknya pernah dirawat di rumah sakit jiwa sehingga dapat mengurangi tingkat kekambuhan pasien, semakin tinggi tingkat resiliensi keluarga, maka semakin jarang frekuensi kekambuhan, berlaku pula sebaliknya yaitu semakin rendah tingkat resiliensi keluarga maka sering frekuensi kekambuhan (Yunika Nur Mastiyas,2017). pada kenyataan nya ada keluarga yang mendukung penuh anaknya yang mau berbaur dengan lingkungan sekitar,dan ada yang sangat khawatir dengan tetangga lingkungan sekitar mengetahui anaknya pernah dirawat di rumah sakit jiwa lebih memilih untuk menutup diri dan tidak terlibat dalam kegiatan masyarakat. Selain itu keterhubungan merupakan hal yang penting dimiliki oleh keluarga khususnya orang yang selama ini merawat anggota keluarga nya yang mengalami gangguan jiwa keterhubungan yang dijalin bisa keterhubungan emosional ataupun saling mendukung, bekerja sama, komitmen, serta 
tetap menghormati perbedaan, keinginan, dan batasan individu.

Keterhubungan tersebut ditunjukan dengan hubungannya pasien dengan keluarga besar nya atau sanak saudara pasien berkenaan dengan tanggung jawab keluarga dalam merawat dan memberikan tempat tinggal kepada pasien pada kenyaataan dari hasil wawancara salah satu keluarga pasien tidak mau merawat atau tinggal bersama dengan pasien akan tetapi ada juga keluarga yang mau merawat dan tinggal bersama pasien. Selain itu berdasarkan aspek dari resiliensi keluarga pasien berkenaan dengan sumber daya sosial ekonomi yang menjadi tangung jawab keluarga dalam merawat pasien skizofrenia.

Kondisi seperti ini terlihat ketika keluarga mengalami kesulitan dalam menghadapi masalah di dalam keluarga, maka mereka cenderung akan meminta bantuan di luar seperti keluarga besar, teman,dan tetangga. Selain itu, untuk dapat memperkuat keberfungsiannya, keluarga juga harus memperoleh kestabilan ekonomi dengan tetap menjaga keseimbangan antara pekerjaan dan kehidupan keluarga kondisi pemenuhan ekonomi pun tergantung dari kondisi keluarga itu sendiri ada dari hasil wawancara dan observasi, yang menjadi tulang punggung keluarga dan membantu memenuhi kebutuhan keluarga serta pasien yaitu kakaknya. Selain itu sumber daya sosial dan ekonomi di pengaruhi oleh struktur keluarga ada struktur keluarga yang sudah tidak lengkap yang disebabkan oleh perceraian sehingga menyebabkan anak tertua menjadi tulang punggung keluarga

Aspek resiliensi keluarga yang lain yaitu, proses komunikasi antar keluarga yang terjalin dalam menangani dan merawat anggota keluarga yang memiliki gangguan jiwa skizofrenia merupakan hal yang sangat penting dimana anggota keluarga khususnya yang berperan sebagai orang yang secara langsung merawat dan mengetahui kondisi anggota keluarganya mengalami gangguan jiwa pasti merasakan hambatan dan kesulitan selama merawat khususnya yang berkaitan dengan perawatan pasien skizofrenia. Tidak adanya pengetahuan yang cukup tentang gangguan jiwa terutama skizofrenia memunculkan ekspresi emosi tinggi terhadap significant others pasien tersebut (Kartika Perwara sari,2018) maka dari itu proses komunikasi yang terjalin baik didalam keluarga tersebut diharapkan menjadi suatu kemudahan bagi significant others yang secara langsung merawat pasien dirumah untuk mengungkapkan perasaan nya kepada anggota keluarga nya yang lain akan tetapi hal ini tidak terjadi dengan mudah padahal pada kenyataan nya significant other memiliki beban mental tersendiri yang harus dikomunikasikan kepada angota keluarga lain, akan tetapi hal ini dipengaruhi oleh seberapa kedekatan significant other terhadap orang yang diyakini nyaman menjadi tempat bercerita, Selain itu upaya pemecahan masalah secara kolaboratif pun menjadi ciri keluarga tersebut bisa dikatakan resilience dari adanya komunikasi yang baik antara significant other dengan anggota keluarga yang lain sehingga apabila adanya masalah keluarga mampu menemukan jalan penyelesaian masalah tersebut.

\section{KESIMPULAN}

Hasil penelitian ini menunjukan bahwa keluarga pasien skizofrenia yang telah selesai dirawat di Rumah Sakit Jiwa dan saat ini harus melanjutkan perawatan dirumah proses pemulihannya dipengaruhi oleh kondisi resiliensi keluarganya. Pada penelitian ini 
terdapat keluarga yang tidak memiliki kondisi keluarga yang resilien hal ini terjadi karena hambatan-hambatan yang terjadi didalam keluarga untuk membangun resiliensi keluarga itu sendiri hambatan tersebut yaitu memiliki keterkaitan satu sama lain yang bermula pada peristiwa lampau yang membuat keretakan didalam keluarga dan keterkaitannya dengan kondisi skizofrenia yang dialami oleh anggota keluarga tersebut sehingga mempengaruhi kondisi pola hubungan dan komunikasi yang terjadi dan berdampak pada pemulihan dari anggota keluarga tersebut.

Pemulangan pasien yang terjadi di Rumah Sakit Jiwa Provinsi Jawa Barat tidak melihat kondisi dari keluarga orang yang akan merawat dan lingkungan sosial yang sangat berpengaruh pada pemulihannya. Sehingga peneliti mengusulkan program "Pendampingan psikosial pasien skizofrenia pasca rawat di Rumah Sakit Jiwa Provinsi Jawa Barat" . Tujuan umum program ini adalah meningkatnya kemampuan informan didalam keluarga dalam merawat anggota keluarga yang mengalami skizofrenia dirumah. Harapan dari program ini keluarga mendapatkan pendampingan dari pihak Rumah Sakit Jiwa Provinsi Jawa Barat untuk membantu membangun dan mempertahankan resiliensi keluarga demi upaya pemulihan anggota keluarga nya yang mengalami skizofrenia. Kegiatan dari pendampingan tersebut merupakan sosialisai kepada keluarga pasien dan home visit / home care yang juga menerapkan model locality development untuk membantu keluarga menciptakan lingkungan sosial yang mendukung pasien dalam pemulihan nya dirumah tanpa takut adanya stigma dan labelling atau sampai pengusiran dari masyarakat setempat. Karena pemulihan yang terbaik bagi orang dengan gangguan jiwa merupakan yang berasal dari dukungan keluarga dan lingkungan sosial yang dapat mendukung dan mendampingi disetiap proses pemulihannya.

\section{DAFTAR PUSTAKA}

Adi Fahrudin. (2009). Membangun sinergitas pelayanan medis dan peningkatan peran pekerja sosial medik di rumah sakit. Makalah

Anggraeni R.R (2008) Resiliensi pada penyandang tuna daksa pasca kecelakaan. Depok. Gunadarma

Candra\&Muhammad (2019) Resiliensi pada keluarga sebagai caregiver pasien skizofrenia dengan kekambuhan. Jurnal Psikologi.6(2) 2-3

Euis Sunarti. Studi ketahanan keluarga dan ukuran:telaah kasus pengaruhnya terhadap kualitas kehamilan.Fakultas Kesehatan Masyarakat Institut Pertanian Bogor. Gizi Masyarakat dan Sumberdaya Keluarga. Disertasi

Fauziah Sefrina (2016) Hubungan keluarga dan keberfungsian sosial pasien rawat jalan. Jurnal Ilmiah Psikologi Terapan.4(2)3-6

Hawabi. A.I. (2011). Pengaruh resiliensi terhadap juvenile delincuency mahasiswa fakultas psikologi universitas islam negeri maulana malik ibrahim malang. Fakultas Psikologi Universitas Islam Negeri Maulana Malik Ibrahim Malang. Skripsi

Marry Jhonston. Relasi dinamis antara pekerja sosial dengan klien dalam setting rumah sakit.Poltekesos Bandung

Kalil,A. (2003). Family resilience and good child outcomes. Wellington : Ministry of Social Development.

Mawarpury\&Firza (2017) Resiliensi keluarga dalam perspektif psikologi. Jurnal Psikoislamedia.2(1)

Maslim, R., (2001) Buku saku diagnosis gangguan jiwa rujukan ringkas dari 
PPDGJ III. Bagian Ilmu Kedokteran Jiwa. FK Unika. Jakarta

Patterson.J. M. (2002). Understanding family resilience. jurnal of clinical psychology. 58(3) 233-246

Wiwin Hendriani.(2017) Resiliensi psikologis sebuah pengantar. Surabaya Prenamedia Grup

Wiramiharja (2017) Psikologi klinis (Edisi Revisi). Bandung Refika Aditama

Walsh,F. (2006). Strengthening family resilience.New York. The Guildford Press Yustinus Semiun.(2006) Kesehatan mental jilid I . Yogyakarta. Kanisius 